\title{
A three-step diagnosis of pediatric pneumonia at the emergency department using clinical predictors, $\mathrm{C}$-reactive protein, and pneumococcal PCR
}

\author{
Gabriel Alcoba $^{1,2}$ (D) $\cdot$ Kristina Keitel $^{3,4}$ - Veronica Maspoli ${ }^{1}$ - Laurence Lacroix ${ }^{1}$. \\ Sergio Manzano ${ }^{1} \cdot$ Mario Gehri $^{5} \cdot$ René Tabin $^{6}$ • Alain Gervaix ${ }^{1}$. \\ Annick Galetto-Lacour ${ }^{1}$
}

Received: 17 October 2016/Revised: 3 April 2017 / Accepted: 18 April 2017 /Published online: 4 May 2017

(C) Springer-Verlag Berlin Heidelberg 2017

\begin{abstract}
Recommendations for the management of community-acquired pneumonia (CAP) advocate that, in the absence of the clinical and laboratory findings typical of bacterial CAP, antibiotics are not required. However, the true value of the clinical and laboratory predictors of pediatric CAP still needs to be assessed. This prospective cohort study in three emergency departments enrolled 142 children with radiological pneumonia. Pneumonia with lung consolidation was the primary endpoint; complicated pneumonia (bacteremia, empyema, or pleural effusion) was the secondary endpoint. We showed that three clinical signs (unilateral hypoventilation, grunting, and absence of wheezing), elevated procalcitonin (PCT), $\mathrm{C}$-reactive protein (CRP), negative nasopharyngeal viral
\end{abstract}

Communicated by Communicated by Nicole Ritz

Gabriel Alcoba

gabriel.alcoba@hcuge.ch

Kristina Keitel

kristina.keitel@unibas.ch

Veronica Maspoli

tardieu.maspoli@gmail.com

Laurence Lacroix

laurence.lacroix@hcuge.ch

Sergio Manzano

sergio.manzano@hcuge.ch

Mario Gehri

mario.gehri@chuv.vd

René Tabin

rene.tabin@hopitalvs.ch
PCR, or positive blood pneumococcal PCR (P-PCR) were significantly associated with both pneumonia with consolidation and complicated pneumonia. Children with negative clinical signs and low CRP values had a low probability of having pneumonia with consolidation (13\%) or complicated pneumonia (6\%). Associating the three clinical signs, CRP $>80 \mathrm{mg} / \mathrm{L}$ and a positive $\mathrm{P}$ PCR ruled in the diagnosis of complicated pneumonia with a positive predictive value of $75 \%$.

Conclusion: A model incorporating clinical signs and laboratory markers can effectively assess the risk of having pneumonia. Children with negative clinical signs and low CRP are at a low risk of having pneumonia. For children with positive clinical signs and high CRP, a positive blood pneumococcal
Alain Gervaix

alain.gervaix@hcuge.ch

Annick Galetto-Lacour

annick.galetto@hcuge.ch

1 Division of Pediatric Emergency Medicine, Department of Child and Adolescent Medicine, Geneva University Hospitals and University of Geneva, Geneva, Switzerland

2 Division of Tropical and Humanitarian Medicine, Geneva University Hospitals (Hôpitaux Universitaires de Genève, HUG), Rue Gabrielle-Perret-Gentil 4, CH-1211 Genève 14, Switzerland

3 Boston Children's Hospital, Boston, MA, USA

4 Swiss Tropical and Public Health Institute, Basel, Switzerland

5 Lausanne University Hospital, Lausanne, Switzerland

6 Valais Hospital, Sion, Switzerland 
PCR can more accurately confirm the diagnosis of pneumonia.

\section{What is Known:}

- Distinguishing between bacterial and viral pneumonia in children is challenging.

- Reducing the inappropriate use of antibiotics is a priority.

What is New:

- Children with negative clinical signs and low C-reactive protein (CRP) values have a low probability of having pneumonia.

- Children with high CRP values can be tested using a pneumococcal PCR to rule in the diagnosis of pneumonia with a high positive predictive value.

Keywords S. pneumoniae $\cdot$ M. pneumoniae $\cdot$ Respiratory viruses $\cdot \mathrm{PCR} \cdot$ Pneumonia $\cdot \mathrm{C}$-reactive protein .

Procalcitonin $\cdot$ Children

$\begin{array}{ll}\text { Abbreviations } \\ \text { CAP } & \text { Community-acquired pneumonia } \\ \text { CI } & \text { Confidence interval } \\ \text { CRP } & \text { C-reactive protein } \\ \text { IQR } & \text { Interquartile range } \\ \text { LytA } & \text { Autolysin A } \\ \text { NP viral } & \text { Nasopharyngeal viral PCR } \\ \text { PCR } & \\ \text { OR } & \text { Odds ratio } \\ \text { PCR } & \text { Polymerase chain reaction } \\ \text { PCT } & \text { Procalcitonin } \\ \text { PCV-7 } & \text { Seven-valent pneumococcal conjugate vaccine } \\ \text { Ply } & \text { Pneumolysin } \\ \text { P-PCR } & \text { Pneumococcal (Streptococcus pneumoniae) } \\ & \text { PCR } \\ \text { PPV } & \text { Positive predictive value } \\ \text { NPV } & \text { Negative predictive value } \\ \text { SP } & \text { Streptococcus } \\ & \text { pneumoniae }=\text { S. pneumoniae }=\text { pneumococcus } \\ \text { WBC } & \text { White blood cell } \\ \text { WB-LytA } & \text { Whole-blood Autolysin A pneumococcal PCR } \\ \text { WB-Ply } & \text { Whole-blood Pneumolysin pneumococcal PCR }\end{array}$

\section{Introduction}

Community-acquired pneumonia (CAP) remains the leading cause of childhood mortality worldwide [2, 11, 12]. Streptococcus pneumoniae (SP) is the main pathogen of bacterial CAP [4] and of pneumonia with complications such as pleural effusion, empyema, or bacteremia [13]. The annual incidence of CAP in Europe and North America is 30-40 per 1000 children $<5$ years old $[29,33,39]$. The microbiological etiologies of childhood CAP vary greatly between studies:
19-65\% are viruses, $19-37 \%$ are typical and atypical bacteria, and $23-33 \%$ are mixed viral-bacterial infections [4, 35, 45].

Unfortunately, a microbiological diagnosis is often impossible due to the inaccessibility of the infected sites, i.e., lung tissue or bronchoalveolar lavage, and this is further complicated by the fact that there is still no gold standard test for the diagnosis of pediatric CAP $[6,30]$. Blood or pleural cultures are very specific but are only positive for CAP in about 4$10 \%$ of cases [7, 10, 43]. Blood pneumococcal PCR assays, targeting genes such as autolysin A (LytA) or pneumolysin (PLY), seem to be more sensitive than blood cultures for diagnosing pneumococcal CAP $[19,40]$ and are used as surrogate markers of pneumococcal pneumonia [1, 25, 47]. However, recent studies have shown that PLY PCR may lack specificity. This is because it can be positive in children with pneumococcal or $S$. viridans colonization, especially in nasopharyngeal PCR $[19,20,36]$. Therefore, the utilization of blood, rather than nasopharyngeal PCR targeting both PLY and LytA genes, seems to be more specific. Bronchoalveolar lavage or lung aspirates are too dangerous for routine testing. Obtaining sputum from young children is difficult and it is also often contaminated by commensals from the oropharynx. Nasopharyngeal bacterial cultures are often positive but can be unreliable due to healthy bacterial carriage. In contrast to adults [14], the rapid urine SP C-polysaccharide assay has shown high rates of false positives in children [15, 17], although recent studies have shown its possible added value $[6,24]$. Antibody responses to four pneumococcal surface protein antibodies and one pneumolysin antibody have displayed encouraging results [41], but they cannot be interpreted until the second week after sampling.

In conclusion, laboratory tests are unreliable at predicting causative bacterial involvement. The British Thoracic Society's recent guidelines for the management of CAP therefore propose that blood testing and chest radiography should not be considered routine investigations [27]. Furthermore, the recent PIDS and IDSA guidelines on pediatric CAP do not recommend the use of antibiotics in the absence of clinical or laboratory findings suggestive of bacterial infection. However, an exact definition of the findings that allow differentiation between bacterial and viral infection are not straightforward. Since there is no gold standard method for differentiating between bacterial and viral pneumonia, the majority of children are indeed treated with antibiotics, often with broad-spectrum antibiotics [31, 46], despite the high incidence of viral pneumonia, notably in children under 2 years old [3]. Developing clinical or laboratory markers that could predict the bacterial etiology of CAP in a more reliable fashion would benefit patients and physicians [6, 23]. The recent guidelines also recommend more rigorous management and follow-up of CAP patients with such complications as bacteremia or empyema. 
The present study aimed to investigate approaches combining clinical and biological markers that would more accurately predict viral, bacterial, and complicated CAP.

\section{Methods}

\section{Ethics statement}

Ethical approval was obtained from the three participating hospitals' relevant research ethics committees: Geneva's Cantonal Research Ethics Committee; the Human Research Ethics Committee of the Canton Vaud, in Lausanne; and the Canton Valais Medical Ethics Committee, in Sion. Written informed consent was obtained from all the participants' parents and from teenage participants themselves, before enrollment.

\section{Design}

A multi-center prospective diagnostic study was conducted in the Pediatric Emergency Departments of three Swiss tertiary hospitals (Geneva, Lausanne, and Sion). We consecutively included 142 children who presented with pneumonia at one of these departments from January 2008 to July 2009. Inclusion criteria were $\geq 2$ months old and $\leq 16$ years old, fever $\left(>38^{\circ} \mathrm{C}\right)$, cough, increased respiratory rate or respiratory distress, and infiltrates on chest radiographs. Exclusion criteria were immunodeficiency, chronic lung or heart diseases, and hospital-acquired pneumonia.

Blinded chest radiographs were examined by pediatric radiologists. Infiltrates visible on chest radiographs were classified as infiltrates with consolidation when there was a dense opacity, with or without air bronchograms, occupying a portion of a lobe, and as infiltrates without consolidation when densities were linear and patchy in a lacy pattern, as per the Bulletin of the World Health Organization [5]. CAP with consolidation was considered a proxy for bacterial pneumonia [38] and was our primary endpoint for the first prediction model. Complicated pneumococcal CAP, defined as CAP with bacteremia, pleural effusion, or empyema, was the endpoint for the second prediction model.

Each participant was investigated with regard to the following data: age, sex, vaccination status, day care attendance, number of siblings, tobacco exposure, clinical examination (respiratory rate, respiratory distress, chest indrawing, nasal flaring, wheezing, unilateral hypoventilation, crackles, oxygen saturation), chest radiograph, WBC count, CRP and PCT levels, blood cultures, blood pneumococcal PCR (PPCR), NP viral PCR, and mycoplasma/chlamydia PCR. The seven-valent pneumococcal vaccine $(\mathrm{PCV}-7)$ was in use at that time.

\section{Laboratory methods}

Blood and nasopharyngeal samples were immediately stored at $-80^{\circ} \mathrm{C}$. Blood P-PCR assays targeting pneumolysin (WBPly) and autolysin A (WB-LytA) were performed in triplicates, as follows. DNA extraction and qPCR: a mixture containing $100 \mu \mathrm{L}$ of whole blood, $100 \mu \mathrm{L}$ of TE buffer $(10 \mathrm{mM}$ Tris- $\mathrm{HCl} \mathrm{pH} 8,1 \mathrm{mM}$ EDTA), and $100 \mu \mathrm{L}$ glass beads (acid washed, 212-300 $\mu \mathrm{m}$, SIGMA) were vortexed for $1 \mathrm{~min}$. Samples were centrifuged at $6000 \mathrm{rpm}$ for $3 \mathrm{~min}$ at room temperature. DNA was extracted from the supernatant using a DNeasy kit (QIAGEN) and eluted in $70 \mu \mathrm{L}$ water. Quantitative PCR was run on a StepOne ${ }^{\mathrm{TM}}$ Real-Time PCR System (Applied Biosystems) using an ABsolute qPCR Mix (Abgene). Reaction mixtures contained $8 \mu \mathrm{L}$ DNA extract and $50 \mathrm{nM}$ primers and probe in a total volume of $20 \mu \mathrm{L}$. Cycling conditions included $2 \mathrm{~min}$ at $50{ }^{\circ} \mathrm{C}, 15 \mathrm{~min}$ at $95^{\circ} \mathrm{C}$, followed by 50 cycles at $95{ }^{\circ} \mathrm{C}$ for $15 \mathrm{~s}$ and $60^{\circ} \mathrm{C}$ for $80 \mathrm{~s}$. Specific primers and probes for WB-LytA and WB-Ply were: LytA_F5' ACGCAATCTAGCAGATGAAGC, LytA_R5'TGTTTGGT TGGTTATTCGTGC, Lyt $A$ Probe_5'-FAM-TTTGCCGA AAACGCTTGATACAGGG [32], Ply_F5'-TGCA GAGCGTCCTTTGGTCTAT, P1y_R5'-CTCT TACTCGTGGTTTCCAACT, Ply_Probe_5'-FAMTGGCGCCCATAAGCAACACTCGAA [8].

NP viral PCR assays were performed as per a previously published protocol [42]. These assays identified a standard panel of 24 viruses: influenza (A, B), parainfluenza $(1,2,3)$, picornavirus, rhinovirus $(A, B)$, enterovirus $(A, B, C, D)$, human meta-pneumovirus (A, B), respiratory syncytial virus (A, B), adenovirus (A, B, C, E), and coronavirus (229E, HKU1, NL63, OC43). CRP values were determined in blood using immunometric methods (Nycocard CRP) according to the manufacturer's instructions. Procalcitonin (PCT) values were determined using the Kryptor® (Brahms GmbH, Germany) assay according to the manufacturer's instructions.

\section{Statistics}

Three types of predictors were analyzed: (1) clinical signs; (2) inflammatory markers, CRP, and PCT; and (3) specific blood pneumococcal, nasopharyngeal viral, and mycoplasma PCRs.

Univariate and multivariate logistic regressions were calculated using STATA ${ }^{\circledR} 11.0$ software (StataCorp, Texas, USA). These tested the associations between CAP with or without consolidation and CAP with or without complications and clinical signs, CRP and PCR, two types of blood P-PCR targeted for WB-LytA and WB-Ply, and nasopharyngeal viral PCR. Medians were expressed using interquartile ranges (IQRs). Measures of effect were expressed using odds ratios (ORs) with $95 \%$ confidence intervals (CIs). Non-parametric Wilcoxon-Mann-Whitney rank-sum tests were used for continuous variables, assuming non-normal distributions. For 
categorical data, Pearson's Chi-squared test and univariate logistic regression were used to establish the presence or absence of general associations. Stepwise multivariate logistic regression analyzed potential confounders. The $p$ value significance level was set at 0.05 .

The performance of each type of predictor was expressed using sensitivity, specificity, positive predictive value (PPV) and negative predictive value (NPV), positive and negative likelihood ratios, and odd ratios. We developed two models involving three diagnostic steps: (1) clinical signs, (2) inflammatory markers (CRP), and (3) specific blood pneumococcal PCR. Likelihood ratios and the Fagan nomogram [22] were used to calculate post-test probabilities step by step. Post-test probabilities were then calculated after each diagnostic step (clinical, CRP, PCR) and expressed in a pre- and post-test flow diagram.

\section{Results}

Of 142 children with pneumonia included in this study, from 3 months to 15 years old (median 3.15 years), 50 (35\%) had CAP with consolidation and $92(65 \%)$ had CAP without consolidation. Twenty-six (18\%) children presented with complicated pneumonia, including 8 bacteremias, 10 empyemas, and 15 pleural effusions. In this cohort, SP was the only bacterium responsible for bacteremia (positive blood culture), pleural effusion, or empyema (positive pleural culture or PCR). Indeed, no staphylococcus, group A streptococcus, or haemophilus were detected.

A total of 44 patients were blood P-PCR positive (41 for WB-Ply, 16 for WB-LytA, and 13 for both), 8 were NP mycoplasma-PCR positive, and 51 were NP viral PCR positive. Some overlapping PCRs were found: 17 were pneumococcal and viral positive; 3 were pneumococcal and mycoplasma positive.

Table 1 shows the baseline characteristics of CAP with and without consolidation and of pneumonia with or without complications. Children presenting with CAP with consolidation or a complication were significantly older. No significant differences were noted in the distribution of other baseline variables.

The clinical model was built using the only three clinical signs that were significantly associated with CAP with consolidation: no wheezing (no need for bronchodilators), unilateral hypoventilation, and grunting. Having at least two of the

Table 1 Demographic, clinical, and biological predictors comparing pneumonia with vs. without consolidation and complicated vs. non-complicated pneumonia

\begin{tabular}{|c|c|c|c|c|}
\hline Variables $N(\%)$ & $\begin{array}{l}\text { With consolidation } \\
50 / 142(35.2 \%)\end{array}$ & $\begin{array}{l}\text { Without consolidation } \\
92 / 142(64.8 \%)\end{array}$ & $\begin{array}{l}\text { Complicated (effusion, } \\
\text { empyema, or } \\
\text { bacteremia) } 25 / 142 \\
(17.6 \%)\end{array}$ & $\begin{array}{l}P \text { values with or without } \\
\text { consolidation/ } \\
\text { complicated vs. } \\
\text { uncomplicated }\end{array}$ \\
\hline
\end{tabular}

Demographic data

$\begin{array}{lcc}\text { Age, years, median (IQR) } & 4.05(2.55-5.17) & 2.95(1.52-4.85) \\ \text { Sex (f, \%) } & 50.0 \%(25 / 50) & 52.2 \%(48 / 92) \\ \text { Day-care/school } & 78.0 \%(39 / 50) & 62.2 \%(56 / 90) \\ \text { Tobacco exposure } & 19.2 \%(9 / 47) & 34.5 \%(30 / 89) \\ \text { No. siblings }>1 & 63.3 \%(31 / 49) & 60.7 \%(54 / 89) \\ \text { Up-to-date PCV-7 } & 34.7 \%(17 / 49) & 37.8 \%(34 / 90) \\ \text { Clinical features } & & \\ \text { No wheezing } & 96.0 \%(48 / 50) & 74.7 \%(68 / 91) \\ \text { Unilateral hypoventilation } & 16.0 \%(8 / 50) & 4.4 \%(4 / 91) \\ \text { Grunting } & 32.0 \%(16 / 50) & 17.4 \%(16 / 92) \\ \text { At least 2 of the 3 above }{ }^{\mathrm{a}} & 34.0 \%(17 / 50) & 16.3 \%(15 / 92) \\ \text { Biological markers } & & \\ \text { PCT: ng/mL, median (IQR) } & 5.94(1.04-14.08) & 0.75(0.20-3.43) \\ \text { CRP: mg/L, median (IQR) } & 144(70-200) & 37(13-108) \\ \text { NP Virus } & 23.4 \%(11 / 47) & 45.5 \%(40 / 88) \\ \text { WB-LytA } & 16 \%(8 / 50) & 8.7 \%(8 / 92) \\ \text { WB-Ply } & 38 \%(19 / 50) & 23.9 \%(22 / 92)\end{array}$

$\begin{array}{cl}4.28(2.36-7.68) & .028 / .04^{\mathrm{b}} \\ 38.5 \%(10 / 26) & >.05 />.05 \\ 64.0 \%(16 / 25) & >.05 />.05 \\ 22.7 \%(5 / 22) & >.05 />.05 \\ 70.8 \%(17 / 24) & >.05 />.05 \\ 26.9 \%(7 / 26) & >.05 />.05 \\ & \\ 96.2 \%(24 / 25) & .002 / .04^{\mathrm{b}} \\ 19.2 \%(5 / 25) & .018 / .03^{\mathrm{b}} \\ 50 \%(13 / 26) & .047 /<.001^{\mathrm{b}} \\ 50 \%(13 / 26) & .016 /<.001^{\mathrm{b}} \\ & \\ 10.1(2.14-27.9) & <.001 /<.001^{\mathrm{b}} \\ 197.5(138-200) & <.001 /<.001^{\mathrm{b}} \\ 16 \%(4 / 25) & .012 / .013^{\mathrm{b}} \\ 38.5 \%(10 / 26) & .189 /<.001^{\mathrm{b}} \\ 53.9 \%(14 / 26) & .077 / .002^{\mathrm{b}}\end{array}$

$I Q R$ interquartile range (between 25 th and 75 th percentiles)

${ }^{\text {a }}$ Clinical model considered positive if 2 of 3 clinical features positive (grunting, unilateral hypoventilation/bronchial breathing, or no wheezing)

${ }^{\mathrm{b}}$ Remains significant $(p<0.05)$ after multivariate analysis with potential confounders (age, day-care, tobacco, and vaccination) 
three clinical signs was very significantly associated with pneumonia with consolidation $(\mathrm{OR}=2.64$ [95\% CI $1.18-$ 5.92], $p<0.018$ ); thus, the model seemed appropriate for use as the first step in post-test estimation.

PCT and CRP values showed excellent $p$ values $(\leq 0.001)$ for distinguishing CAP with consolidation. A negative test for NP viral PCR was associated with CAP with consolidation $(p=0.012)$. Blood P-PCR only showed very strong $p$ values $(\leq 0.002)$ for discriminating between complicated and uncomplicated pneumonia, but not between CAP with or without consolidation. Even after controlling for potential confounders (age, day-care, tobacco, and vaccination), multivariate logistic regression showed that these significant associations between clinical and biological variables and CAP with consolidation remained significant.

A comparison of CRP and PCT values using specific microbiological PCR results (Table 2) showed significant differences. Children with positive pneumococcal WB-LytA presented very high median CRP and PCT values, significantly different to WB-LytA negative ones. Positive NP viral PCR was associated with lower median CRP values than negative NP viral cases. Positive mycoplasma NP PCR was associated with low PCT values, significantly different from negative mycoplasma NP PCR. In this study, PCT levels predicted Mycoplasma pneumoniae better than CRP did, and CRP levels distinguished viruses better than PCT did.

Performance testing of different markers (Table 3 ) showed that the clinical model worked very well for CAP with consolidation and complicated pneumonia (both specificities: $84 \%$ ); however, it was not sensitive enough. The most sensitive biomarkers of pneumonia with consolidation were obtained by adding CRP and PCT at low cut-offs: the sensitivity of the clinical model with CRP was $92 \%$ and with PCT was $90 \%$. Maximum specificity was found by combining high inflammatory markers (CRP or PCT) with positive pneumococcal
PCR (WB-LytA). Adding a negative NP, viral PCR result increased its specificity even more.

Regarding biomarkers of complicated pneumonia (with bacteremia, pleural effusion, or empyema), maximal sensitivity $(92.3 \%$ ) was achieved using CRP or PCT (with the same low cut-offs). However, optimal specificity was achieved by associating high levels of these inflammatory markers with blood pneumococcal PCR (WB-LytA) (specificity 96.6\%) or, for an even better result, also associating a negative NP viral PCR (specificity $=98.3 \%$ ).

A model was constructed to associate clinical findings (two of three clinical signs) as a first step, adding CRP as a second step, and blood pneumococcal PCR as a third step. CRP was used instead of PCT due to its stronger association with the diagnosis of pneumonia (higher OR). Figure 1 shows how the post-test probability of complicated pneumonia increased from $18.3 \%$ (known prevalence = pre-test probability for this population: $26 / 142$ ) to $40.6 \%$ with a positive clinical model result, to $52.0 \%$ with a $\mathrm{CRP}$ above $80 \mathrm{mg} / \mathrm{L}$, and to a much stronger $85.7 \%$ if WB-LytA was positive. In contrast, it decreased to $11.8 \%$ if clinical signs were absent and to below $3 \%$ if CRP was $<80 \mathrm{mg} / \mathrm{L}$. The prediction of pneumonia with consolidation was also greatly improved by using these three steps, although with a lower CRP cut-off ( $40 \mathrm{mg} / \mathrm{L}$ ) and using WB-Ply PCR, which was more sensitive than WB-LytA for the diagnosis of non-complicated pneumonia.

\section{Discussion}

In this study, we showed that a model combining negative clinical signs with low levels of inflammatory markers could identify children at a low risk of pneumonia with consolidation. Having two out of three clinical signs-unilateral hypoventilation, grunting, and an absence of wheezing-
Table 2 Comparison of Creactive protein and procalcitonin according to the microbiological results (pneumococcal, viral, and mycoplasma PCRs) for 142 children with clinical pneumonia

\begin{tabular}{|c|c|c|c|c|}
\hline \multirow[b]{2}{*}{ PCR } & \multicolumn{2}{|c|}{ C-reactive protein $(\mathrm{mg} / \mathrm{L})$} & \multicolumn{2}{|c|}{ Procalcitonin $(\mathrm{ng} / \mathrm{mL})$} \\
\hline & Median (IQR) & $P$ values ${ }^{\mathrm{a}}$ & Median (IQR) & $P$ values ${ }^{\mathrm{a}}$ \\
\hline \multicolumn{5}{|c|}{ Pneumococcal whole blood Lyt-A PCR } \\
\hline Positive $(n=16)$ & $193.5(140-200)$ & & $10.14(3.74-21.8)$ & \\
\hline Negative $(n=126)$ & $57.5(18-147.5)$ & .0011 & $1.04(0.24-5.94)$ & .0015 \\
\hline \multicolumn{5}{|c|}{ Viral nasopharyngeal PCR } \\
\hline Positive $(n=51)$ & $29(11-65)$ & & $0.80(0.25-2.81)$ & \\
\hline Negative $(n=84)$ & $106(34-200)$ & .0003 & $2.96(0.26-11.1)$ & .0575 \\
\hline \multicolumn{5}{|c|}{ Mycoplasma nasopharyngeal PCR } \\
\hline Positive $(n=8)$ & $35(10-80)$ & & $0.10(0.06-0.18)$ & \\
\hline Negative $(n=134)$ & $70(20-178)$ & .16 & $1.70(0.35-9.97)$ & .0005 \\
\hline
\end{tabular}


Table 3 Performance testing of different markers

\begin{tabular}{|c|c|c|c|c|c|c|c|}
\hline Pneumonia with consolidation $(n=50 / 142)$ & OR $(95 \% \mathrm{CI})$ & Sensitivity $\%$ & Specificity $\%$ & PPV & NPV & LR+ & LR- \\
\hline Clinical model $^{\mathrm{a}}$ & $2.64(1.18-5.92)$ & 72.0 & 48.9 & 43.9 & 75.9 & 1.41 & 0.57 \\
\hline $\mathrm{PCT}>2 \mathrm{ng} / \mathrm{mL}$ & $4.20(1.97-8.99)$ & 67.4 & 67.1 & 55.9 & 76.8 & 2.04 & 0.48 \\
\hline PCT $>0.5 \mathrm{ng} / \mathrm{mL}$ & $3.82(1.64-8.91)$ & 81.6 & 46.3 & 48.8 & 80.4 & 1.52 & 0.40 \\
\hline $\mathrm{CRP}>80 \mathrm{mg} / \mathrm{L}$ & $6.39(2.91-13.9)$ & 73.5 & 69.7 & 58.1 & 82.2 & 2.43 & 0.38 \\
\hline $\mathrm{CRP}>40 \mathrm{mg} / \mathrm{L}$ & $5.12(2.15-12.2)$ & 83.7 & 50.0 & 48.8 & 84.3 & 1.67 & 0.32 \\
\hline WB-LytA+ positive & $1.95(0.68-5.56)$ & 16.0 & 91.1 & 50.0 & 66.1 & 1.80 & 0.92 \\
\hline WB-Ply+ positive & $1.89(0.89-3.99)$ & 38.0 & 75.6 & 46.3 & 68.7 & 1.55 & 0.82 \\
\hline NP virus- negative & $2.59(1.17-5.75)$ & 76.6 & 44.2 & 42.9 & 77.6 & 1.37 & 0.52 \\
\hline Clinical model and PCT $(<0.5 \mathrm{ng} / \mathrm{mL})$ & $3 . .09(1.13-8.42)$ & 90.0 & 25.6 & 40.2 & 82.1 & 1.21 & 0.39 \\
\hline Clinical model and CRP $(<40 \mathrm{mg} / \mathrm{L})$ & $4.93(1.68-14.4)$ & 92.0 & 30.0 & 42.2 & 87.1 & 1.31 & 0.27 \\
\hline Clinical model and CRP $(>80 \mathrm{mg} / \mathrm{L})$ & $5.04(2.36-10.8)$ & 54.0 & 81.1 & 61.4 & 76.0 & 2.86 & 0.57 \\
\hline Clinical model and PCT (>2 ng/mL) & $3.79(1.81-7.95)$ & 52.0 & 77.8 & 56.5 & 74.5 & 2.34 & 0.62 \\
\hline $\mathrm{CRP}>80$ and $\mathrm{Ply}+$ & $6.11(2.37-15.7)$ & 34.0 & 92.2 & 70.8 & 71.6 & 4.37 & 0.72 \\
\hline $\mathrm{CRP}>80$ and $\mathrm{LytA}+$ & $2.66(0.87-8.18)$ & 16.0 & 93.3 & 57.1 & 66.7 & 2.40 & 0.90 \\
\hline $\mathrm{CRP}>80$ and LytA+ and NP virus- & $2.77(0.87-8.76)$ & 14.0 & 94.4 & 58.3 & 64.4 & 2.52 & 0.91 \\
\hline Clinical model, CRP $>80$, Ply + & $5.97(2.05-17.3)$ & 26.5 & 94.4 & 72.2 & 69.7 & 4.62 & 0.78 \\
\hline Clinical model, CRP $>80$, LytA + & $4.10(1.23-13.5)$ & 16.0 & 95.6 & 66.7 & 67.2 & 3.60 & 0.88 \\
\hline $\begin{array}{l}\text { Complicated pneumonia with bacteremia } \\
\text { or effusion }(n=26 / 142)\end{array}$ & OR $(95 \% \mathrm{CI})$ & Sensitivity $\%$ & Specificity $\%$ & PPV & NPV & LR+ & LR- \\
\hline Clinical model $^{\mathrm{a}}$ & $4.96(1.67-14.6)$ & 84.6 & 47.4 & 26.5 & 93.2 & 1.61 & 0.32 \\
\hline PCT $>2$ ng/mL & $5.47(2.07-14.4)$ & 76.9 & 62.1 & 33.9 & 91.4 & 2.03 & 0.37 \\
\hline PCT $>0.5 \mathrm{ng} / \mathrm{mL}$ & $5.49(1.64-18.2)$ & 88.5 & 41.7 & 27.7 & 93.5 & 1.52 & 0.28 \\
\hline $\mathrm{CRP}>80 \mathrm{mg} / \mathrm{L}$ & $22.7(5.1-101.4)$ & 92.3 & 65.5 & 38.7 & 97.3 & 2.67 & 0.11 \\
\hline $\mathrm{CRP}>40 \mathrm{mg} / \mathrm{L}$ & $10.0(2.25-44.4)$ & 92.3 & 45.5 & 28.6 & 96.2 & 1.69 & 0.17 \\
\hline WB-LytA+ positive & $11.5(3.66-35.8)$ & 38.5 & 94.8 & 62.5 & 87.3 & 7.43 & 0.64 \\
\hline WB-Ply+ positive & $3.85(1.59-9.30)$ & 53.8 & 76.7 & 34.1 & 88.1 & 2.31 & 0.60 \\
\hline $\mathrm{NP}$ virus - negative & $3.91(1.26-12.2)$ & 84.0 & 42.7 & 25.0 & 92.2 & 1.47 & 0.37 \\
\hline Clinical model and PCT $(<0.5 \mathrm{ng} / \mathrm{mL})$ & $3.47(0.77-15.6)$ & 92.3 & 22.4 & 21.1 & 92.9 & 1.19 & 0.43 \\
\hline Clinical model and CRP (<40 mg/L) & $3.07(0.89-18.0)$ & 92.3 & 25.0 & 21.6 & 93.5 & 1.23 & 0.31 \\
\hline Clinical model and CRP $(>80 \mathrm{mg} / \mathrm{L})$ & $23.5(7.35-75.1)$ & 84.6 & 81.0 & 50.0 & 95.9 & 4.46 & 0.19 \\
\hline Clinical model and PCT (>2 ng/mL) & $7.07(2.82-17.7)$ & 69.2 & 75.9 & 39.1 & 91.7 & 2.87 & 0.41 \\
\hline $\mathrm{CRP}>80 \mathrm{mg} / \mathrm{L}, \mathrm{Ply}+$ & $12.4(4.52-33.4)$ & 53.8 & 91.4 & 58.3 & 89.8 & 6.24 & 0.51 \\
\hline $\mathrm{CRP}>80 \mathrm{mg} / \mathrm{L}, \mathrm{LytA}+$ & $17.5(5.12-59.2)$ & 38.5 & 96.6 & 71.4 & 87.5 & 11.1 & 0.63 \\
\hline CRP $>80$ mg/L, WB-LytA+, NP virus- & $35.6(7.2-177.5)$ & 38.5 & 98.3 & 83.3 & 87.7 & 22.3 & 0.62 \\
\hline Clinical model, $\mathrm{CRP}>80, \mathrm{Ply}+$ & $22.2(7.02-69.8)$ & 50.0 & 95.7 & 72.2 & 89.5 & 11.0 & 0.52 \\
\hline Clinical model, CRP >80, LytA+ & $19.9(5.2-75.0)$ & 34.6 & 97.4 & 75.0 & 86.9 & 13.4 & \\
\hline
\end{tabular}

$P C T$ procalcitonin, $C R P$ C-reactive protein, $W B$ whole blood PCR, $P l y$ pneumolysin, $L y t A$ autolysin, $N P$-virus nasopharyngeal viral PCR, $P P V$ positive predictive value, $N P V$ negative predictive value

a 2 of 3 clinical signs: wheezing absent, unilateral hypoventilation present, grunting present

showed good specificity for identifying CAP with consolidation but was not very sensitive.

The lack of sensitivity of clinical signs has been emphasized previously $[6,9]$. Thus, we evaluated a model combining clinical signs and inflammatory markers.

Recent studies demonstrated that these markers were useful for predicting the bacterial etiology of CAP [1, 18, 21, 25] and that PCT and CRP values were better than WBC count for differentiating bacterial from viral CAP [28]. Furthermore, in the present study, children with positive blood pneumococcal PCR or negative NP viral PCR had higher levels of inflammatory markers. We subsequently showed that adding CRP (cut-off $40 \mathrm{mg} / \mathrm{L}$ ) as a second step to the model allowed us to rule out pneumonia with excellent sensitivity (92\%) and with a negative predictive value of $87 \%$ for pneumonia with consolidation and $94 \%$ for complicated pneumonia.

Children with negative clinical signs and low CRP were at a low risk of pneumonia. The challenge in the setting of a 
Pneumonia with consolidation $\left(n^{*}=47 / 136\right)$

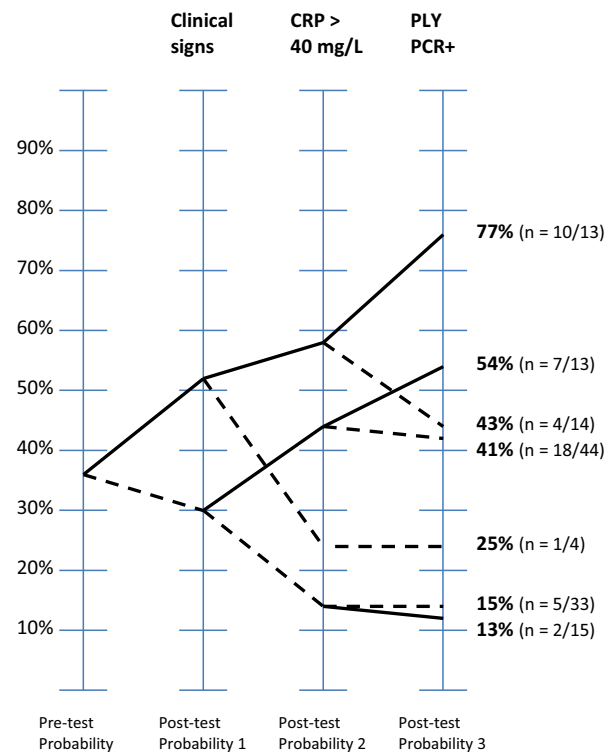

Fig. 1 Post-test probability of typical lobar pneumonia or complicated pneumonia with the three-step assessment: (1) clinical model, (2) Creactive protein $>80 \mathrm{mg} / \mathrm{L}$, and (3) whole-blood pneumococcal PCRs (PLY specific for typical lobar pneumonia, LYT-A specific for complicated pneumonia) based on the prevalence (pre-test probability). Abbreviations: $L R$ likelihood ratio for a positive test $(L R+)$ and a negative

consultation in an emergency department is the identification and treatment of children at a high risk of developing pneumonia with consolidation while minimizing unnecessary investigations, treatment, or hospital admissions for children with self-limiting viral respiratory illnesses. The negative predictive value of the rules developed here allowed us to identify which children, from among all those with fever and tachypnea, were at a low risk of pneumonia with consolidation and thus required neither a chest radiograph nor immediate antibiotic treatment. This rule is applicable within the time frame allotted for an emergency consultation as a clinical evaluation and CRP value are rapidly available. The present study confirmed that rules associating clinical signs with inflammatory markers could identify children with a low risk of pneumonia [40].

In order to more reliably rule in the diagnosis of pneumonia with consolidation, we combined clinical signs and CRP with a third step using blood pneumococcal PCR markers. The post-test probability of pneumonia with consolidation for a child with positive clinical signs, high CRP, and positive blood pneumococcal PLY PCR reached $77 \%$, and the PPV was $72 \%$. Different models for predicting pneumonia have been studied recently. Erdman et al. developed a model associating CRP and Chitinase 3-like-1 which could rule in radiological pneumonia with a lower PPV of 54\% [19]. Elemraid et al. constructed a model based on age, CRP, and a neutrophil

\section{Complicated pneumonia}

$\left(n^{*}=26 / 130\right)$

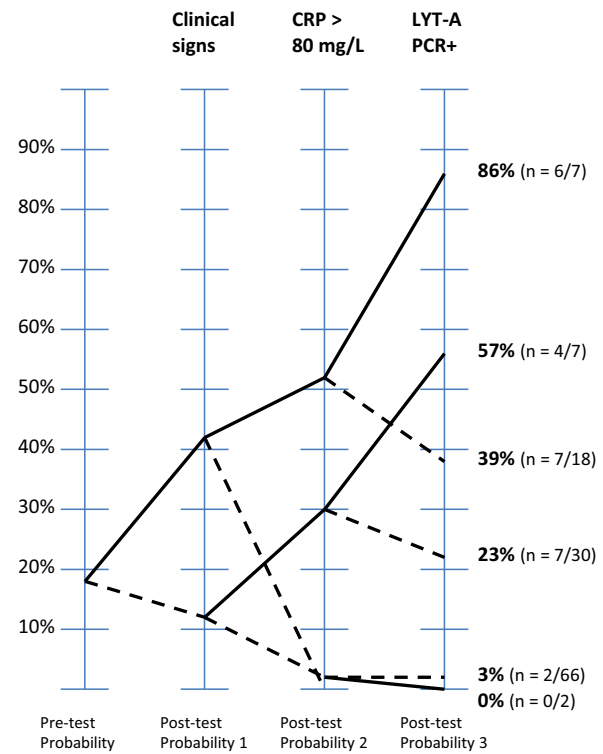

test (LR-). Impact of LR+ is shown by straight black lines; impact of LR - by dotted lines. Clinical model: positive $=2$ out of 3 features are present; $P L Y+$ and $L Y T-A+$ positive pneumococcal whole-blood PCRs (Pneumolysin or Autolysin). *post-test probabilities are calculated for patients with complete laboratory workup

count with a $75 \%$ sensitivity and a $91 \%$ PPV for the diagnosis of radiologically confirmed pneumonia [18]. Finally, we previously developed a model using CRP or PCT, associated with a positive pneumococcal urinary antigen, which could predict pneumococcal pneumonia with a similar (75-83\%) PPV [24]. These different models re-emphasize the central role that CRP or PCT have in the prediction of pneumonia.

Although identifying children at a high risk of pneumonia with consolidation is important, rapidly identifying children at risk of pneumonia with complications such as bacteremia, pleural effusion, or empyema is also necessary. These children require immediate management with investigation and often intravenous antibiotics and hospital admission. The three-step model presented here, involving clinical signs, high CRP, and positive blood P-PCR increases the post-test probability of complicated pneumonia from 52 to $87 \%$. It is worth noting that the blood pneumococcal PCR was most useful in the group of children with high levels of inflammatory markers. This might be explained by the fact that the group of children with high levels of inflammatory markers probably had a high prevalence of pneumococcal pneumonia and, therefore, the influence of false-positive PCR results, due to nasopharyngeal colonization, may be reduced. Associating a negative NP virus PCR further increased the positive likelihood ratio to 22 , allowing the identification of children at a high risk of complications. 
The role of blood and NP PCR in patient management will probably evolve in the future. Previously, viral or pneumococcal PCR was a standard method for etiological diagnosis in research studies [13, 20, 36, 47]. However, since the development of rapid multiplex PCR systems that integrate sample preparation, amplification, detection, and analysis, such as FilmArray ${ }^{\circledR}$, PCR may come to have a more significant impact on patient management than previously anticipated. With the need for just a few minutes of hands-on-time and results available in less than $1 \mathrm{~h}$, multiplex PCR can work within the time frame of an emergency consultation, something that was impossible before. The results of pneumococcal and viral PCR examinations could thus be used rapidly in a decisionmaking model for patient therapy.

With regard to etiology, Mycoplasma pneumoniae PCR was positive in fewer than $6 \%$ of cases and only in children $>5$ years old. CRP did not differentiate between mycoplasma pneumonia and other types of pneumonia, as previously underscored by Medjo et al. [34]. With regard to PCT, mycoplasma pneumonia was associated with lower PCT values than non-mycoplasma pneumonia, as previously reported by Moulin et al. [37].

One of the main limitations of the present study, common to all bacterial pneumonia studies, is the lack of a gold standard etiological diagnosis. Radiologically confirmed pneumonia has been used as a proxy for bacterial pneumonia in numerous studies on epidemiological investigations [3], clinical trials of antimicrobial agents [26], and conjugate pneumococcal vaccine efficacy [44]. Recently, Nascimento-Carvalho et al. determined that pneumonia with alveolar consolidation had a $93 \%$ sensitivity for pneumococcal infection [38]. We therefore validated our diagnosis of pneumonia by radiologically confirming pneumonia with consolidation even though the limits to this method's reliability are well known [16].

A second limitation is the relatively low median age of the study population, which could be a bias toward the viral etiology of infections as lower age is linked to viral etiology [18]. However, this age group does represent the typical pneumonia population encountered in a pediatric emergency department $[16,21]$.

Furthermore, the positive results of this three-step method, using clinical and laboratory markers, need to be externally validated with a different population before being proposed more widely for the management of children with pneumonia.

In conclusion, the risk of pneumonia can be assessed using the three-step workup described herein. Step one is to identify children with "positive clinical signs," such as unilateral hypoventilation, grunting, and absence of wheezing. Step two is to measure CRP. For children with positive clinical signs and high inflammatory markers; step three could be measuring blood pneumococcal PCR in order to more effectively identifying children with pneumonia with consolidation or a complication. For children with negative markers, future studies proposing safety-netting with a clinical follow-up at $48 \mathrm{~h}$, but no immediate antibiotic treatment or chest radiograph, should be scheduled.

This study adds information that may be useful in implementing current guidelines for the management of pneumonia. This could reduce consumption of antibiotics, decrease resistance, and save unnecessary investigations.

Acknowledgements We declare that all the authors have seen and approved the final manuscript, contributed significantly to the work, and that the manuscript has neither been previously published nor is it being considered for publication elsewhere. GA and AGL had full access to all of the data in the study and take responsibility for the integrity of the data and the accuracy of the data analysis. We would like to thank and acknowledge the extensive help of Ms. Florence Hugon for the organization of files, follow-up, transport and storage of samples, and for her fantastic energy.

Authors' contributions We declare that all the authors have contributed to this study. AG, AGL, KK, MG, RT, and GA participated in the design. AG, AGL, KK, MG, RT, VM, LL, and SM participated actively in implementing the study and collecting data. KK, VM, and GA contributed to the construction and cleaning of the database. GA performed most of the statistical analyses and wrote the initial manuscript. All authors participated in the revision of the manuscript and the design of figure and tables. AGL and AG actively supervised the whole process.

\section{Compliance with ethical standards}

Funding This study was funded by the Geneva University Hospitals, Division of Pediatric Emergency Medicine (Professor Alain Gervaix).

Ethical approval All the procedures performed in studies involving human participants were in accordance with the ethical standards of the institutional and/or national research committee and with the 1964 Declaration of Helsinki and its later amendments or comparable ethical standards.

Informed consent Written informed consent was obtained from all the participants' parents, and the teenage participants themselves, before enrollment.

Conflict of interest The authors declare that they have no conflict of interest.

\section{References}

1. Berg AS, Inchley CS, Fjaerli HO, Leegaard TM, Lindbaek M, Nakstad B (2017) Clinical features and inflammatory markers in pediatric pneumonia: a prospective study. Eur J Pediatr. doi:10. 1007/s00431-017-2887-y

2. Black RE, Cousens S, Johnson HL, Lawn JE, Rudan I, Bassani DG, Jha P, Campbell H, Walker CF, Cibulskis R et al (2010) Global, regional, and national causes of child mortality in 2008: a systematic analysis. Lancet 375(9730):1969-1987

3. Cantais A, Mory O, Pillet S, Verhoeven PO, Bonneau J, Patural H, Pozzetto B (2014) Epidemiology and microbiological investigations of community-acquired pneumonia in children admitted at the emergency department of a university hospital. J Clin Virol 60(4):402-407 
4. Cevey-Macherel M, Galetto-Lacour A, Gervaix A, Siegrist CA, Bille J, Bescher-Ninet B, Kaiser L, Krahenbuhl JD, Gehri M (2009) Etiology of community-acquired pneumonia in hospitalized children based on WHO clinical guidelines. Eur J Pediatr 168(12): $1429-1436$

5. Cherian T, Mulholland EK, Carlin JB, Ostensen H, Amin R, de Campo M, Greenberg D, Lagos R, Lucero M, Madhi SA et al (2005) Standardized interpretation of paediatric chest radiographs for the diagnosis of pneumonia in epidemiological studies. Bull World Health Organ 83(5):353-359

6. Clark JE (2015) Determining the microbiological cause of a chest infection. Arch Dis Child 100(2):193-197

7. Coon ER, Maloney CG, Shen MW (2015) Antibiotic and diagnostic discordance between ED physicians and hospitalists for pediatric respiratory illness. Hosp Pediatr 5(3):111-118

8. Corless CE, Guiver M, Borrow R, Edwards-Jones V, Fox AJ, Kaczmarski EB (2001) Simultaneous detection of Neisseria meningitidis, Haemophilus influenzae, and Streptococcus pneumoniae in suspected cases of meningitis and septicemia using real-time PCR. J Clin Microbiol 39(4):1553-1558

9. Craig JC, Williams GJ, Jones M, Codarini M, Macaskill P, Hayen A, Irwig L, Fitzgerald DA, Isaacs D, McCaskill M (2010) The accuracy of clinical symptoms and signs for the diagnosis of serious bacterial infection in young febrile children: prospective cohort study of 15781 febrile illnesses. BMJ 340:c1594

10. Dagan R, Shriker O, Hazan I, Leibovitz E, Greenberg D, Schlaeffer F, Levy R (1998) Prospective study to determine clinical relevance of detection of pneumococcal DNA in sera of children by PCR. J Clin Microbiol 36(3):669-673

11. Dagan R, Bhutta ZA, de Quadros CA, Garau J, Klugman KP, Khuri-Bulos N, Levine O, Saha SK, Sow S, Were F et al (2010a) The remaining challenge of pneumonia: the leading killer of children. Pediatr Infect Dis J

12. Dagan R, Quadros CA, Garau J, Klugman KP, Khuri-Bulos N, Levine O, Sow S, Yang Y (2010b) Marking November 12, 2010 - World Pneumonia Day: where are we, where are vaccines? Hum Vaccin 6(11):922-925

13. De Schutter I, Vergison A, Tuerlinckx D, Raes M, Smet J, Smeesters PR, Verhaegen J, Mascart F, Surmont F, Malfroot A (2014) Pneumococcal aetiology and serotype distribution in paediatric community-acquired pneumonia. PLoS One 9(2):e89013

14. Dominguez J, Gali N, Blanco S, Pedroso P, Prat C, Matas L, Ausina V (2001) Detection of Streptococcus pneumoniae antigen by a rapid immunochromatographic assay in urine samples. Chest 119(1): 243-249

15. Dominguez J, Blanco S, Rodrigo C, Azuara M, Gali N, Mainou A, Esteve A, Castellvi A, Prat C, Matas L et al (2003) Usefulness of urinary antigen detection by an immunochromatographic test for diagnosis of pneumococcal pneumonia in children. J Clin Microbiol 41(5):2161-2163

16. Don M, Valent F, Korppi M, Canciani M (2009) Differentiation of bacterial and viral community-acquired pneumonia in children. Pediatrics international : official journal of the Japan Pediatric Society 51(1):91-96

17. Dowell SF, Garman RL, Liu G, Levine OS, Yang YH (2001) Evaluation of Binax NOW, an assay for the detection of pneumococcal antigen in urine samples, performed among pediatric patients. Clin Infect Dis 32(5):824-825

18. Elemraid MA, Rushton SP, Thomas MF, Spencer DA, Gennery AR, Clark JE (2014) Utility of inflammatory markers in predicting the aetiology of pneumonia in children. Diagn Microbiol Infect Dis 79(4):458-462

19. Erdman LK, D'Acremont V, Hayford K, Rajwans N, Kilowoko M, Kyungu E, Hongoa P, Alamo L, Streiner DL, Genton B et al (2015) Biomarkers of host response predict primary end-point radiological pneumonia in Tanzanian children with clinical pneumonia: a prospective cohort study. PLoS One 10(9). doi:10.1371/journal. pone. 0137592

20. Esposito S, Marchese A, Tozzi AE, Rossi GA, Da Dalt L, Bona G, Pelucchi C, Schito GC, Principi N, Italian Pneumococcal CAPG (2012) Bacteremic pneumococcal community-acquired pneumonia in children less than 5 years of age in Italy. Pediatr Infect Dis J 31(7):705-710

21. Esposito S, Di Gangi M, Cardinale F, Baraldi E, Corsini I, Da Dalt L, Tovo PA, Correra A, Villani A, Sacco O et al (2016) Sensitivity and specificity of soluble triggering receptor expressed on myeloid cells-1, midregional proatrial natriuretic peptide and midregional proadrenomedullin for distinguishing etiology and to assess severity in community-acquired pneumonia. PLoS One 11(11): $\mathrm{e} 0163262$

22. Fagan TJ (1975) Letter: nomogram for Bayes theorem. N Engl J Med 293(5):257

23. Florin TA, Ambroggio L (2014) Biomarkers for communityacquired pneumonia in the emergency department. Curr Infect Dis Rep 16(12):451

24. Galetto-Lacour A, Alcoba G, Posfay-Barbe KM, Cevey-Macherel M, Gehri M, Ochs MM, Brookes RH, Siegrist CA, Gervaix A (2013a) Elevated inflammatory markers combined with positive pneumococcal urinary antigen are a good predictor of pneumococcal community acquired pneumonia in children. Pediatr Infect Dis J

25. Galetto-Lacour A, Alcoba G, Posfay-Barbe KM, Cevey-Macherel M, Gehri M, Ochs MM, Brookes RH, Siegrist CA, Gervaix A (2013b) Elevated inflammatory markers combined with positive pneumococcal urinary antigen are a good predictor of pneumococcal community-acquired pneumonia in children. Pediatr Infect Dis J 32(11): 1175-1179

26. Greenberg D, Givon-Lavi N, Sadaka Y, Ben-Shimol S, Bar-Ziv J, Dagan R (2014) Short-course antibiotic treatment for communityacquired alveolar pneumonia in ambulatory children: a doubleblind, randomized, placebo-controlled trial. Pediatr Infect Dis J 33(2):136-142

27. Harris M, Clark J, Coote N, Fletcher P, Harnden A, McKean M, Thomson A, British Thoracic Society Standards of Care C (2011) British Thoracic Society guidelines for the management of community acquired pneumonia in children: update 2011. Thorax 66(Suppl 2):ii1-i23

28. Hoshina T, Nanishi E, Kanno S, Nishio H, Kusuhara K, Hara T (2014) The utility of biomarkers in differentiating bacterial from non-bacterial lower respiratory tract infection in hospitalized children: difference of the diagnostic performance between acute pneumonia and bronchitis. J Infect Chemother 20(10):616-620

29. Jokinen C, Heiskanen L, Juvonen H, Kallinen S, Karkola K, Korppi M, Kurki S, Ronnberg PR, Seppa A, Soimakallio S et al (1993) Incidence of community-acquired pneumonia in the population of four municipalities in eastern Finland. Am J Epidemiol 137(9):977988

30. Klugman KP, Madhi SA, Albrich WC (2008) Novel approaches to the identification of Streptococcus pneumoniae as the cause of community-acquired pneumonia. Clin Infect Dis 47(Suppl 3): S202-S206

31. Leyenaar JK, Lagu T, Shieh MS, Pekow PS, Lindenauer PK (2014) Variation in resource utilization for the management of uncomplicated community-acquired pneumonia across community and children's hospitals. J Pediatr 165(3):585-591

32. McAvin JC, Reilly PA, Roudabush RM, Barnes WJ, Salmen A, Jackson GW, Beninga KK, Astorga A, McCleskey FK, Huff WB et al (2001) Sensitive and specific method for rapid identification of Streptococcus pneumoniae using real-time fluorescence PCR. J Clin Microbiol 39(10):3446-3451

33. McIntosh $\mathrm{K}$ (2002) Community-acquired pneumonia in children. $\mathrm{N}$ Engl J Med 346(6):429-437 
34. Medjo B, Atanaskovic-Markovic M, Radic S, Nikolic D, Lukac M, Djukic S (2014) Mycoplasma pneumoniae as a causative agent of community-acquired pneumonia in children: clinical features and laboratory diagnosis. Ital J Pediatr 40:104

35. Michelow IC, Olsen K, Lozano J, Rollins NK, Duffy LB, Ziegler T, Kauppila J, Leinonen M, McCracken GH Jr (2004) Epidemiology and clinical characteristics of community-acquired pneumonia in hospitalized children. Pediatrics 113(4):701-707

36. Moisi JC, Makawa MS, Tall H, Agbenoko K, Njanpop-Lafourcade BM, Tamekloe S, Amidou M, Mueller JE, Gessner BD (2017) Burden of pneumococcal disease in northern Togo before the introduction of pneumococcal conjugate vaccine. PLoS One 12(1): e0170412

37. Moulin F, Raymond J, Lorrot M, Marc E, Coste J, Iniguez JL, Kalifa G, Bohuon C, Gendrel D (2001) Procalcitonin in children admitted to hospital with community acquired pneumonia. Arch Dis Child 84(4):332-336

38. Nascimento-Carvalho CM, Araujo-Neto CA, Ruuskanen O (2015) Association between bacterial infection and radiologically confirmed pneumonia among children. Pediatr Infect Dis J 34(5): 490-493

39. O'Brien KL, Wolfson LJ, Watt JP, Henkle E, Deloria-Knoll M, McCall N, Lee E, Mulholland K, Levine OS, Cherian T (2009) Burden of disease caused by Streptococcus pneumoniae in children younger than 5 years: global estimates. Lancet 374(9693):893-902

40. Oostenbrink R, Thompson M, Lakhanpaul M, Steyerberg EW, Coad N, Moll HA (2013) Children with fever and cough at emergency care: diagnostic accuracy of a clinical model to identify children at low risk of pneumonia. Eur J Emerg Med 20(4):273-280

41. Posfay-Barbe KM, Galetto-Lacour A, Grillet S, Ochs MM, Brookes RH, Kraehenbuhl JD, Cevey-Macherel M, Gehri M,
Gervaix A, Siegrist CA 2010 Immunity to pneumococcal surface proteins in children with community-acquired pneumonia: a distinct pattern of responses to pneumococcal choline-binding protein A. Clin Microbiol Infect

42. Raymond F, Carbonneau J, Boucher N, Robitaille L, Boisvert S, Wu WK, De Serres G, Boivin G, Corbeil J (2009) Comparison of automated microarray detection with real-time PCR assays for detection of respiratory viruses in specimens obtained from children. J Clin Microbiol 47(3):743-750

43. 2002) British Thoracic Society guidelines for the management of community acquired pneumonia in childhood. Thorax 57 (Suppl 1): i1-24

44. Tregnaghi MW, Saez-Llorens X, Lopez P, Abate H, Smith E, Posleman A, Calvo A, Wong D, Cortes-Barbosa C, Ceballos A et al (2014) Efficacy of pneumococcal nontypable Haemophilus influenzae protein D conjugate vaccine (PHiD-CV) in young Latin American children: a double-blind randomized controlled trial. PLoS Med 11(6):e1001657

45. Tsolia MN, Psarras S, Bossios A, Audi H, Paldanius M, Gourgiotis D, Kallergi K, Kafetzis DA, Constantopoulos A, Papadopoulos NG (2004) Etiology of community-acquired pneumonia in hospitalized school-age children: evidence for high prevalence of viral infections. Clin Infect Dis 39(5):681-686

46. Wallihan R, Ramilo O (2014) Community-acquired pneumonia in children: current challenges and future directions. J Inf Secur 69(Suppl 1):S87-S90

47. Williams DJ, Zhu Y, Grijalva CG, Self WH, Harrell FE, Jr., Reed C, Stockmann C, Arnold SR, Ampofo KK, Anderson EJ et al (2016) Predicting severe pneumonia outcomes in children. Pediatrics 138(4). doi:10.1542/peds.2016-1019 